\title{
Effect of airflow on biodrying of gar dening wastes in reactors
}

\author{
F. J. Colomer-Mendoza ${ }^{1, *}$, L. Herrera-Prats ${ }^{1}$, F. Robles-Martínez ${ }^{2}$, A. Gallardo- \\ Izquierdo $^{1}$, A.B. Piña-Guzmán ${ }^{2}$
}

1. Department of Mechanical Engineering and Construction, (Universidad Jaume I) Jaume $1^{\text {st }}$ University. Ave. Sos Baynat s/n, Castellón 12071, Spain. E-mail:fcolomer@uji.es

2. Biotechnology Multidisciplinary Professional Unit, (Instituto Politécnico Naciona) National Politechnic Institute. Ave. Acueduct of Guadalupe s/n Barrio la Laguna Ticomán, Gustavo A. Madero 07340, México DF. México

Received 13 July 2012; revised 22 October 2012; accepted 18 December 2012

\begin{abstract}
Biodrying consists of reducing moisture by using the heat from aerobic bio-degradation. The parameters that control the process are: aeration, temperature during the process, initial moisture of biowaste, and temperature and relative humidity of the input air. Lawn mowing and garden waste from the gardens of the University Jaume I, Castellón (Spain) were used as a substrate. Biodrying was performed in 10 reactors with known air volumes from 0.88 to $6.42 \mathrm{~L} /(\mathrm{min} \cdot \mathrm{kg}$ dry weight $(\mathrm{dw}))$. To promote aeration, 5 of the reactors had $15 \%$ of a bulking agent added. The experiment lasted 20 days. After the experiments it was found that the bulking agent led to greater weight loss. However, the increased airflow rate was not linearly proportional to the weight loss.
\end{abstract}

Key words: biodrying; biowaste; stabilization; aerobic fermentation; bulking agent

\section{DOI : 10.1016/S1001-0742(12)60123-5}

${ }^{*}$ Corresponding author.

\section{Introduction}

Biodrying is a variation of aerobic decomposition, used within mechanical-biological treatment (MBT) plants to dry and partially stabilize municipal solid wastes (MSW). In addition, it is a drying technique that relies on the biological activity of microorganisms, both bacteria and fungi, to reduce the moisture content of wet biomaterial waste (Sadaka et al., 
2010), while preserving calorific value (Adani et al., 2002). It is a significant alternative for treating MSW (Velis et al., 2009). Currently, most studies of biodrying processes focus on the aerobic technology, which removes water mainly as vapor by high temperatures and adequate ventilation (Zhang et al., 2008). After biodrying, the refuse can be used as a source of energy, i.e., fuel, (Adani et al., 2002; Sugni et al., 2005) suitable for safe and economical combustion in a biomass boiler (Navaee-Ardeh et al., 2010).

In biodrying, the main drying mechanism is convective evaporation, using heat from the aerobic biodegradation of waste components and facilitated by the mechanically supported airflow. The moisture content of the waste matrix is reduced through two main steps: (1) water molecules evaporate (i.e., change of phase from liquid to gas) from the surface of waste fragments into the surrounding air; and (2) the evaporated water is transported through the matrix by the airflow and removed with the exhaust gases. Limited amounts of free water may seep through the waste matrix and be collected at the bottom of the biodrying reactor as leachate (Velis et al., 2009). Furthermore, there are other parameters controlling biodrying processes, such as type of waste, microorganisms, biomass temperature, water content, aeration, and presence of a bulking agent (BA). In general, biodegradable samples with moisture below $35 \%$ on a wet weight basis will be biologically dormant and consequently, their respiration index will be falsely low (Gomez et al., 2006). Therefore, to maintain the growth and activity of microorganisms it is necessary to add water above all in compost processes (Liang et al., 2003; Tremier et al., 2005; Wagland et al., 2009) but sometimes, biodrying process water is added to promote aerobic fermentation in the hydrolytic stage by means of the recirculation of a part of the leachate generated (Zhang et al., 2009).

Thus, there have been several studies on variations in the above parameters to see how they affect the process of biodrying. Adani et al. (2002) in their investigations with MSW carried out three trials at three different biomass temperatures, obtained by airflow rate control, concluding that biodegradation and biodrying were inversely correlated: fast biodrying produced low biological stability and vice versa. The results of the investigations of Sugni et al. (2005) with MSW suggested that the daily inversion of airflow in biodrying by means of reactors eliminates marked temperature differences and leads to a homogeneous final product. Zhang et al. (2008), in order to improve the water content reduction and accelerated biodegradation of MSW with high water content, supplemented a hydrolytic stage prior to aerobic degradation and inoculated the biomass with the bio-drying products as 
leachate (Zhang et al., 2009). The study of Zhao et al. (2011) had the goal of investigating the interactive influence of airflow rate and turning frequency on water removal and biomass energy utilization for dewatered sludges. Finally, a novel continuous biodrying process carried out by Navaee-Ardeh et al. (2010) was developed in order to increase the dry solids content of sludge to economical levels, rendering it suitable for safe and economical combustion in a biomass boiler. But, in most cases MSW is the main substrate for biodrying.

On the other hand, some investigations have demonstrated the influence of BA in the biodrying process. The results of Zhao et al. (2011) revealed that when using straw, sawdust and their combination as the BA, straw has substantial biodegradation potential in the aerobic process while sawdust has poor capacity to be degraded. Yañez et al. (2009) studied four types of compost in a laboratory reactor, consisting of mixtures of pruning wastes (Acacia dealbata as a BA) with sewage sludge, concluding that the optimal amounts of sewage sludge for co-composting with Acacia indicate that moderate amounts of sludge (1/1) would be the best compromise. Alburquerque et al. (2006) observed that mixing "alperujo" with grape stalk or olive leaf as BA improved the progress of the composting process. Furthermore, both mature composts were equally free of phytotoxicity and showed a similar composition.

The aim of this work was to evaluate and compare the different reductions of moisture according to the airflow supplied in different bio-reactors with grass as a substrate. Moreover, the effectiveness of pruning wastes or wood shavings as BA on the biodrying process was analyzed.

\section{Materialsand methods}

The experimental investigation was performed using 10 experimental reactors $(25 \mathrm{~L})$ which were fed with gardening wastes as biomass. The biodrying reactors were organized in two sets: In Set 1, five reactors were filled with $7 \mathrm{~kg}$ of grass (lawn) and were operated with different airflow ranging from 2 to $10 \mathrm{~L} / \mathrm{min}$. In Set 2, five reactors were filled with $7 \mathrm{~kg}$ of grass and $15 \%$ of BA (pruning waste and wood shavings with particle size between 2 and 3 $\mathrm{cm}$, and initial moisture of $4.33 \%$ ) and operated at the same airflow as Set 1. Gardening wastes were obtained from the gardens of Universidad Jaume I (Castellón, Spain).

The biodrying reactors were built with cylindrical plastic drums of $40 \mathrm{~cm}$ diameter and $62 \mathrm{~cm}$ high with fiberglass insulation around the perimeter and on top. They were installed inside a closed room heated to $25^{\circ} \mathrm{C}$ and $70 \%$ relative humidity. Five different airflows: 1.28 to $6.42 \mathrm{~L} /(\min \cdot \mathrm{kg} \mathrm{dw}$ (grass)) and 0.88 to $4.38 \mathrm{~L} /(\min \cdot \mathrm{kg} \mathrm{dw}$ (grass $+\mathrm{BA})$ ) were supplied by 
forced air driving the air through the reactor by means of four blowers on the bottom of the reactors (Table 1). In all assays, the waste residence time in the reactor was fixed at 20 days. Leachate generated daily was collected from an outlet (open-close) placed at the bottom of the reactor and then the volume was measured (Fig. 1).

Table1 Summary of the ten biodrying experiments

\begin{tabular}{ccccc}
\hline & Reactor & Biowaste & $\begin{array}{c}\text { Initial moisture } \\
(\%)\end{array}$ & $\begin{array}{c}\text { Airflow } \\
(\mathrm{L} /(\mathrm{min} \cdot \mathrm{kg} \mathrm{dw}))\end{array}$ \\
& 1 & Grass & 77.73 & 1.28 \\
\multirow{3}{*}{ Set 1} & 2 & & 2.57 \\
& 3 & & 3.85 \\
& 4 & & 5.13 \\
& 5 & & & 6.42 \\
\hline \multirow{3}{*}{ Set 2} & 6 & Grass $(85 \%)+$ BA $(15 \%)$ & 67.35 & 0.88 \\
& 7 & & & 1.75 \\
& 8 & & & 2.63 \\
& 9 & & 3.50 \\
& 10 & & 4.38 \\
\hline
\end{tabular}

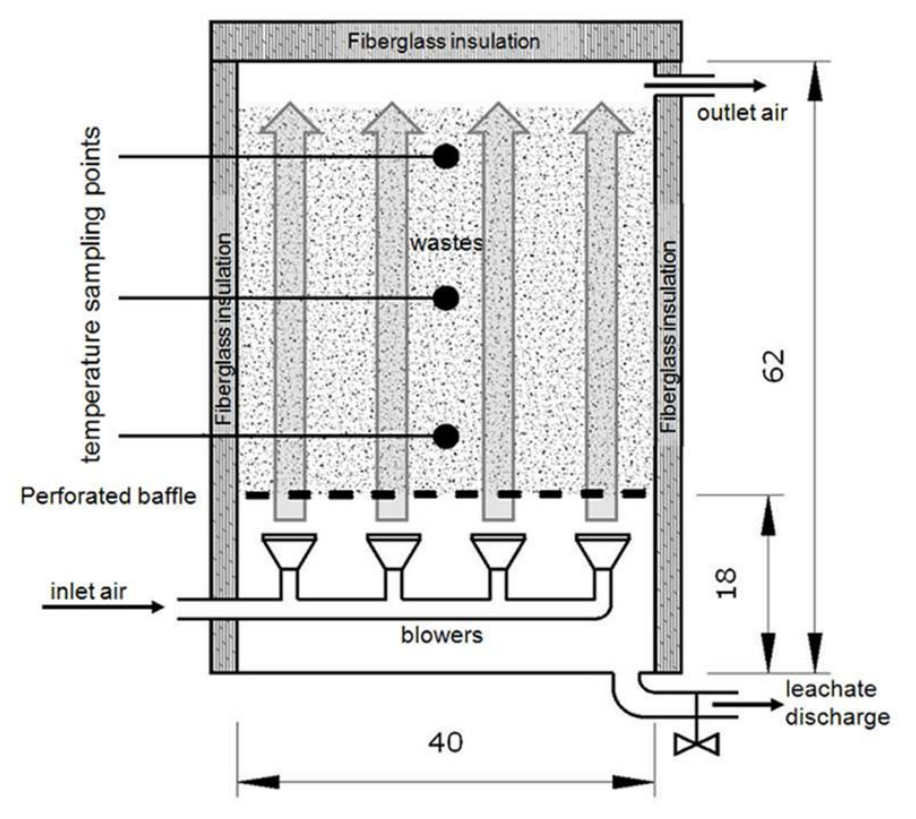

Fig. 1 Scheme of the reactors (dimensions are in $\mathrm{cm}$ ). 
Each reactor had a capacity of $25 \mathrm{~L}$, divided into two compartments; the lower was occupied by four diffusers. A horizontal metal grid separated the lower and the upper part and retained the waste mass. In the loaded reactors, injection airflow was supplied for 20 days $\left(25^{\circ} \mathrm{C}\right.$ and $70 \%$ relative humidity). During this period, the following parameters were monitored: (1) $\mathrm{pH}$ and volume of leachates; (2) weight loss, measured using a portable scale, which is directly related to the loss of moisture from the sample; (3) temperature in the mass of waste ( 3 times/day in the center of the reactors ) by means of a compost probe (Leybold Didactic GmbH model 666 210); (4) reactor outlet gases (12 hours after the beginning of the experiment, 2 times/day): $\mathrm{CH}_{4}, \mathrm{CO}_{2}, \mathrm{O}_{2}, \mathrm{SO}_{2}$, and $\mathrm{NH}_{3}$ by means of a portable analyzer (Dräger model SEP 8314060); (5) temperature and relative humidity of the airflow was measured using the LASCAR EL-USB-2-LCD Data Logger (temperature range: $-35 \sim 80^{\circ} \mathrm{C}$ and humidity range: $0--100 \% \mathrm{RH}$ ). When the dwell time was finished (20 days), representative samples were taken in order to be analyzed. The samples were dried in an oven $\left(105^{\circ} \mathrm{C}, 24 \mathrm{hr}\right)$, in order to determine their moisture content following the ISO 5068-1 standard. Dried waste was ground in a mill so that $98.75 \%$ of the particles could pass through a $2 \mathrm{~mm}$ sieve. In each of the samples, the heating value was determined by means of a 1261 Bomb Calorimeter ${ }^{\circledR}$, PARR, USA, in accordance with ISO 1928:1995. Nitrogen content was analyzed using thermal conductivity equipment (FP-528®, LECO, USA) and carbon was

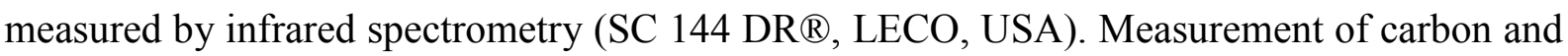
nitrogen content would allow emissions in the incineration process to be estimated in order to avoid the need for process air or off-gas treatment lines.

\section{Results and discussion}

\subsection{Leachate generation}

Leachate was generated only in reactors with lower airflow (133 mL in Reactor 1, 103 $\mathrm{mL}$ in Reactor 2, $150 \mathrm{~mL}$ in Reactor 6, and $10 \mathrm{~mL}$ in Reactor 7). The volume of leachate generated as percent of moisture in both sets of reactors is represented in Table 2. The rest of the water was removed by the combined action of aeration flow and metabolic heat produced by the microorganisms present in the waste. Pruning and gardening wastes produce low volumes of leachates compared to horticultural or fruit wastes, because green wastes have lignin and cellulose in their structure. This characteristic improves the biodrying process of green wastes. 
Table 2 Summary of the data obtained

\begin{tabular}{|c|c|c|c|c|c|c|c|c|}
\hline & Reactor & $\begin{array}{c}\text { Moisture }_{(\mathrm{f})} \\
(\%)\end{array}$ & $\begin{array}{c}\text { Moisture } \\
(\%)\end{array}$ & $\begin{array}{l}\text { Evaporated } \\
\text { water }(\%)\end{array}$ & $\begin{array}{c}\text { Weight } \\
\text { loss } \\
(\%)\end{array}$ & $\begin{array}{c}\text { Energy } \\
\text { consumption } \\
((\mathrm{kW} \cdot \mathrm{hr}) / \mathrm{kg} \\
\mathrm{dw})\end{array}$ & $\begin{array}{l}\mathrm{LHV}_{(\mathrm{f})} \\
(\mathrm{kJ} / \mathrm{kg})\end{array}$ & $\begin{array}{c}\text { Increase } \\
\text { of LHV } \\
(\%)\end{array}$ \\
\hline \multirow{6}{*}{$\begin{array}{c}\text { Set } 1 \\
\text { (Without } \\
\text { BA) }\end{array}$} & \multicolumn{6}{|c|}{ Moisture $_{(\mathrm{i})}=77.73 \%$} & \multicolumn{2}{|c|}{$\mathrm{LHV}_{(\mathrm{i})}=1627.19$} \\
\hline & 1 & 62.97 & 2.39 & 51.29 & 39.86 & 2.15 & 4589 & 182.03 \\
\hline & 2 & 53.05 & 1.89 & 67.65 & 52.57 & 4.32 & 6581 & 304.47 \\
\hline & 3 & 50.51 & 0 & 70.77 & 55.00 & 6.47 & 7090 & 335.72 \\
\hline & 4 & 47.86 & 0 & 73.71 & 57.29 & 8.62 & 7622 & 368.39 \\
\hline & 5 & 43.70 & 0 & 77.76 & 60.43 & 10.79 & 8457 & 419.73 \\
\hline \multicolumn{7}{|c|}{ Moisture $_{(\mathrm{i})}=67.35 \%$} & \multicolumn{2}{|c|}{$\mathrm{LHV}_{(\mathrm{i})}=3990.90$} \\
\hline \multirow{5}{*}{$\begin{array}{l}\text { Set } 2 \\
\text { (With } \\
\text { BA) }\end{array}$} & 6 & 33.56 & 3.18 & 75.58 & 50.86 & 1.48 & 11063 & 172.98 \\
\hline & 7 & 23.31 & 0.21 & 85.35 & 57.43 & 2.94 & 13209 & 230.98 \\
\hline & 8 & 22.00 & 0 & 86.41 & 58.14 & 4.42 & 13483 & 237.64 \\
\hline & 9 & 21.46 & 0 & 86.84 & 58.43 & 5.88 & 13595 & 240.65 \\
\hline & 10 & 20.92 & 0 & 87.26 & 58.71 & 7.36 & 13709 & 243.50 \\
\hline
\end{tabular}

"Percent of moisture, transformed into leachate.

i: initial; f: final.

\subsection{Lower heating value (LHV)}

In addition, the initial and final LHV were analyzed. Obviously, the lower the moisture of waste, the higher the LHV of the waste is. In Reactor 5 the increase of LHV of the biodried waste reached $419.73 \%$, which corresponds to $8457 \mathrm{~kJ} /(\mathrm{kg}$ wet weight (ww)). Reactor 10 had 13,709 $\mathrm{kJ} / \mathrm{kg}$, nevertheless the increase was smaller, 243.5\% (Table 2). Samples of a mixture of grass and BA had a greater value of initial LHV $(3990.90 \mathrm{~kJ} / \mathrm{kg})$ than grass alone $(1627.19 \mathrm{~kJ} / \mathrm{kg})$. This could be explained by the high LHV of pruning waste and wood shavings, and because the initial moisture was lower in reactors with BA than in reactors without BA.

The moisture level reached in the waste after the biodrying process was fairly low in reactors with BA. Considering that a LHV between 8500 and $10,000 \mathrm{~kJ} / \mathrm{kg}$ is recommended for energy recovery of a refuse-derived fuel (RDF) in an incineration plant, the biodried gardening waste using BA could be used for that purpose because of the LHV reached in this work (11,063--13,709 kJ/kg) (Table 2); although the European Association of Waste 
Treatment Companies for Stabilized Wastes (EURITS) establish a LHV > 15,000 kJ/kg ww. on the basis of a RDF quality standard. The values presented in this work are similar to LHV ranges found in other works for dried MSW: 8200--13,813 kJ/kg (Zhang et al., 2009; Sugni et al., 2005) or 14,700--18,800 kJ/kg (Tambone et al., 2011). Shao et al. (2010) increased the LHV of his MSW from 4010 to $10,300 \mathrm{~kJ} / \mathrm{kg}$. Other types of waste with high initial moisture such as sewage sludge have a much greater increase in LHV, e.g., from 500 to $6000 \mathrm{~kJ} / \mathrm{kg}$ (Stasta et al., 2006). Nevertheless, although the LHV of gardening wastes is not as high as that of MSW containing plastics, paper and cardboard in the mixture $(14,500 \mathrm{~kJ} / \mathrm{kg})$, the chlorine content is much lower in green wastes (Velis et al., 2012), this being an additional benefit linked to the use of this kind of waste. According to published data, Velis et al. (2010) studied quality of management initiatives for RDF, as well as quality of MBT plants. The quality of MBT plants was assessed through statistical analysis.

\subsection{Exhaust gascomposition}

Figure $2 \mathbf{a}$ shows the exhaust gas composition of the reactors. On day 1 , in the reactors with grass the $\mathrm{CO}_{2}$ proportion was $8.45 \%$ in Reactor $1,3.26 \%$ in Reactor $2,2.16 \%$ in Reactor 3, $1.89 \%$ in Reactor 4, and $0.46 \%$ in Reactor 5. Nevertheless, this proportion diminished as the days passed. Final values were $0.43 \%, 0.08 \%, 0.05 \%, 0.03 \%$, and $0.03 \%$ in reactors $1,2,3,4$, and 5 , respectively. The higher the airflow, the lower the $\mathrm{CO}_{2}$ concentration in the exhaust gases was. 

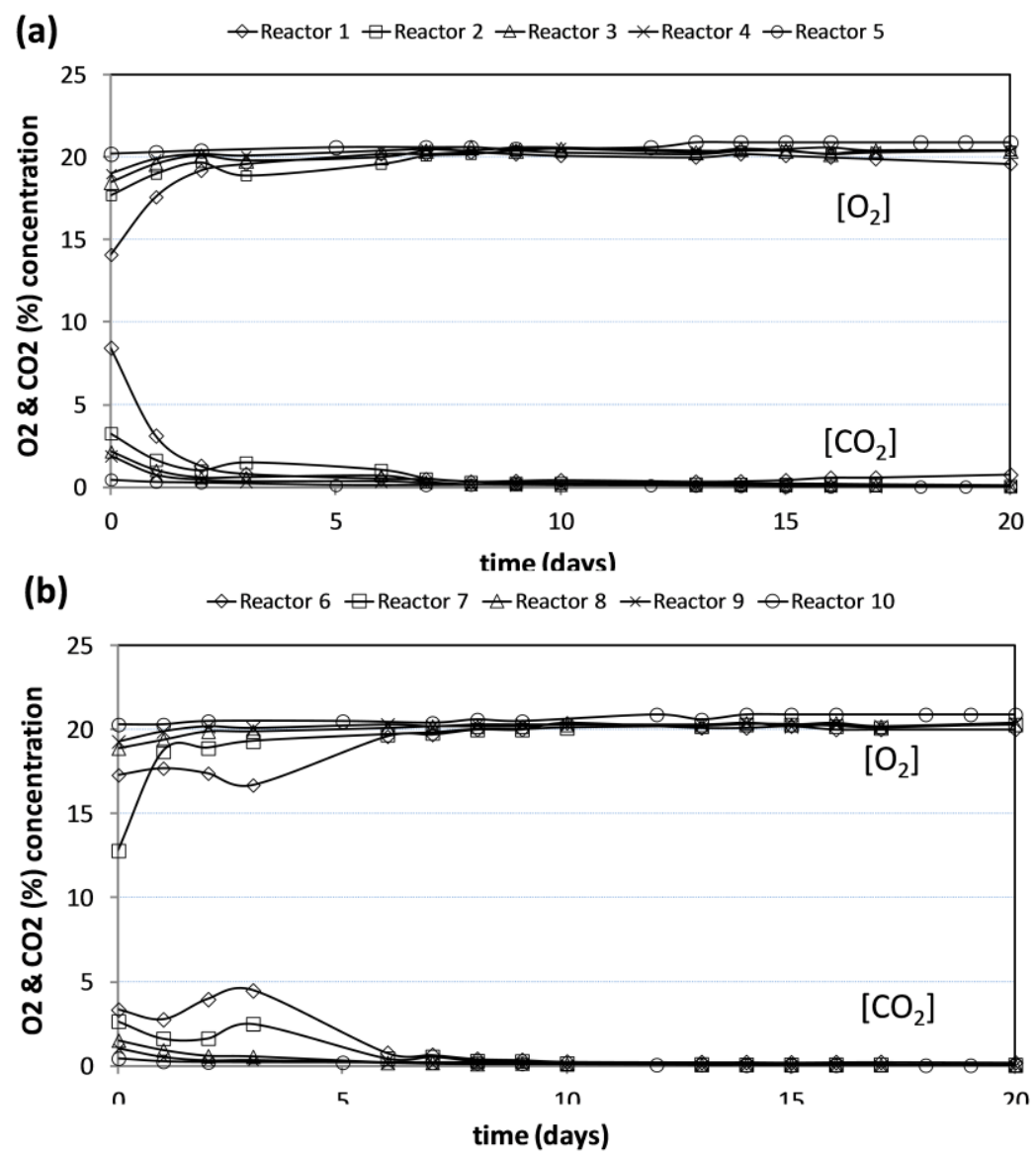

Fig. $2 \mathrm{O}_{2}$ and $\mathrm{CO}_{2}$ proportion in the exhaust gas from reactors. (a) Set 1 (reactors fed with grass), and (b) Set 2 (reactors fed with grass + BA).

The opposite occurred with $\mathrm{O}_{2}$ concentration. On day 1 , the $\mathrm{O}_{2}$ proportion was $14.11 \%$ in Reactor $1 ; 17.74 \%$ in Reactor $2 ; 18.48 \%$ in Reactor 3; $19.03 \%$ in Reactor 4; and $20.20 \%$ in Reactor 5. Final values of $\mathrm{O}_{2}$ were $20.15 \%, 20.31 \%, 20.37 \%, 20.39 \%$, and $20.90 \%$ in reactors $1,2,3,4$, and 5, respectively. The concentration of $\mathrm{NH}_{3}$, a product of waste decomposition, was irregular, reaching values of $141 \mathrm{ppm}$ in Reactor 1, $126 \mathrm{ppm}$ in Reactor 2, $200 \mathrm{ppm}$ in Reactor 3, $197 \mathrm{ppm}$ in Reactor 4, and $15 \mathrm{ppm}$ in Reactor 5. These values were obtained during the first five days of the experiment (day 2 to day 5).

The exhaust gas composition in reactors with BA (reactors 6 to 10) is shown in Fig. 2b. On the first day the $\mathrm{CO}_{2}$ proportion was $3.34 \%$ in Reactor $6,2.65 \%$ in Reactor $7,1.52 \%$ in Reactor $8,1.03 \%$ in Reactor 9, and $0.44 \%$ in Reactor 10 . As in previous cases, the proportion of $\mathrm{CO}_{2}$ decreased as the days passed, reaching values of $0.20 \%, 0.07 \%, 0.03 \%, 0.03 \%$, and $0.03 \%$ in reactors $6,7,8,9$, and 10 respectively. The $\mathrm{O}_{2}$ concentration in the exhaust gas had an opposite behavior, increasing as the days passed. On the first day, the $\mathrm{O}_{2}$ concentration was 
$15.21 \%$ in Reactor 6, $13.89 \%$ in Reactor $7,18.93 \%$ in Reactor $8,19.34 \%$ in Reactor 9, and $20.30 \%$ in Reactor 10 . Final values after 20 days were $20.0 \%, 20.3 \%, 20.4 \%, 20.4 \%$, and $20.9 \%$ in reactors $6,7,8,9$, and 10 , respectively. In both groups, the $\mathrm{CH}_{4}$ concentration in exhaust gases was nil in all cases, since they involved aerobic fermentation. The concentration of $\mathrm{NH}_{3}$, a product of waste decomposition, was irregular, reaching values of 14 ppm in Reactor 6, 17 ppm in Reactor 7, 23 ppm in Reactor 8, 14 ppm in Reactor 9, and 39 ppm in Reactor 10 . These values were very low, probably promoted by the high aeration of the mixture.

\subsection{Temperature evolution}

As depicted in Fig. 3a, during the first two days the temperature evolution within the waste mass followed a behavior quite similar in reactors 1 to 4 (without BA), with a significant increase, reaching $50^{\circ} \mathrm{C}$, while in reactors with BA (Fig. 3b) the temperatures were higher in reactors 6 and 7 (low airflow) than in the rest of the reactors, reaching top values of $52^{\circ} \mathrm{C}$.
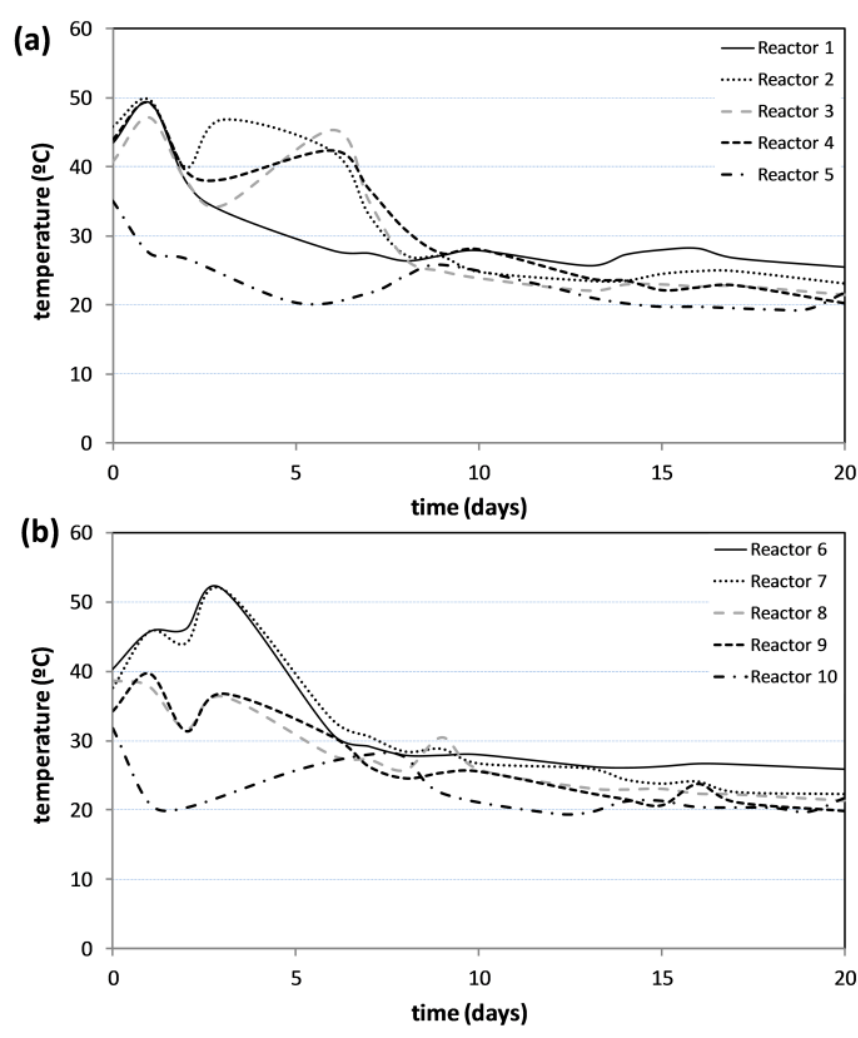

Fig. 3 Evolution of temperature inside the waste mass in reactors. (a) Set 1 (reactors 1--5, fed with grass), and (b) Set 2 (reactors 6--10, fed with grass + BA). 
In reactors 5 and 10 , with the highest airflow, the temperature never surpassed $35^{\circ} \mathrm{C}$. In this case the airflow cooled the waste mass. After 7--8 days, temperature decreased in all the reactors and was not higher than $30^{\circ} \mathrm{C}$.

On the other hand, the increase of temperature $\left(>50^{\circ} \mathrm{C}\right)$ caused by aerobic fermentation and low air supply reduced the strong odors, and has been proposed as a means of reducing and even eliminating pathogens present in livestock waste (Collick et al., 2007) and, in some cases, to remove volatile organic compounds (He et al., 2010) and other pollutants in the air emissions (Ragazzi et al., 2011).

On the other hand, Fig. 4 shows the temperature of the input and output air in the reactors. In reactors with $\mathrm{BA}$, the temperature of output air showed a more homogeneous behavior than in reactors without BA, because the BA improves the air distribution inside the reactors. In reactors with and without BA, the air was heated during the thermophilic phase, in fact the temperature of output air increased as much as $6^{\circ} \mathrm{C}$ compared with the input air. However, after the highest biological activity was finished, the temperature of output air in all reactors was lower that the input temperature, because there was no (or very low) heat production and the water evaporation decreased the temperatures of the waste and air. Both the waste and output air temperatures in reactors with the highest airflow $(10 \mathrm{~L} / \mathrm{min})$ were the lowest. 
(a)

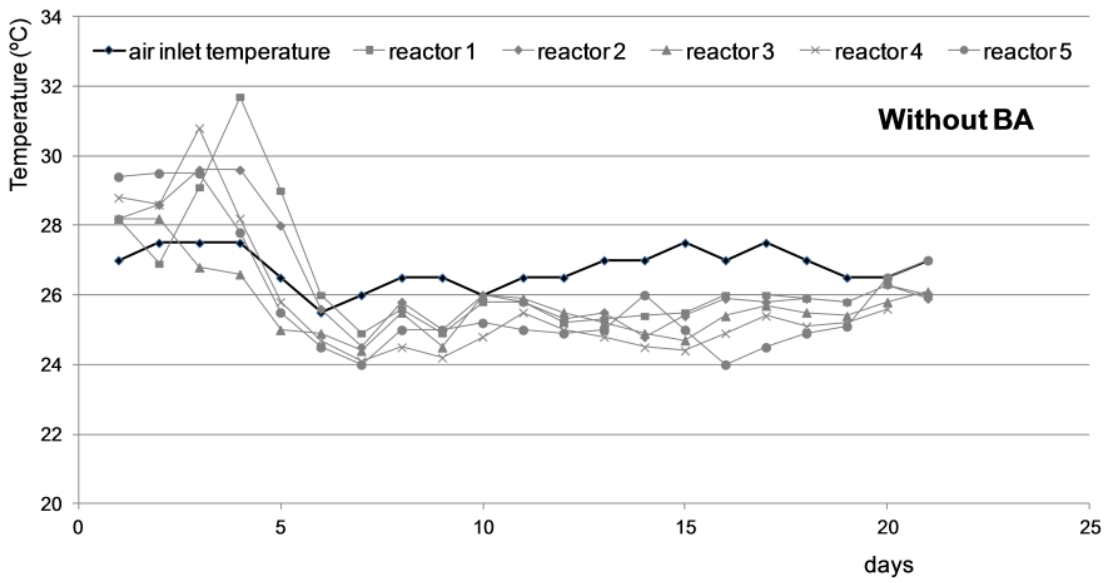

(b)

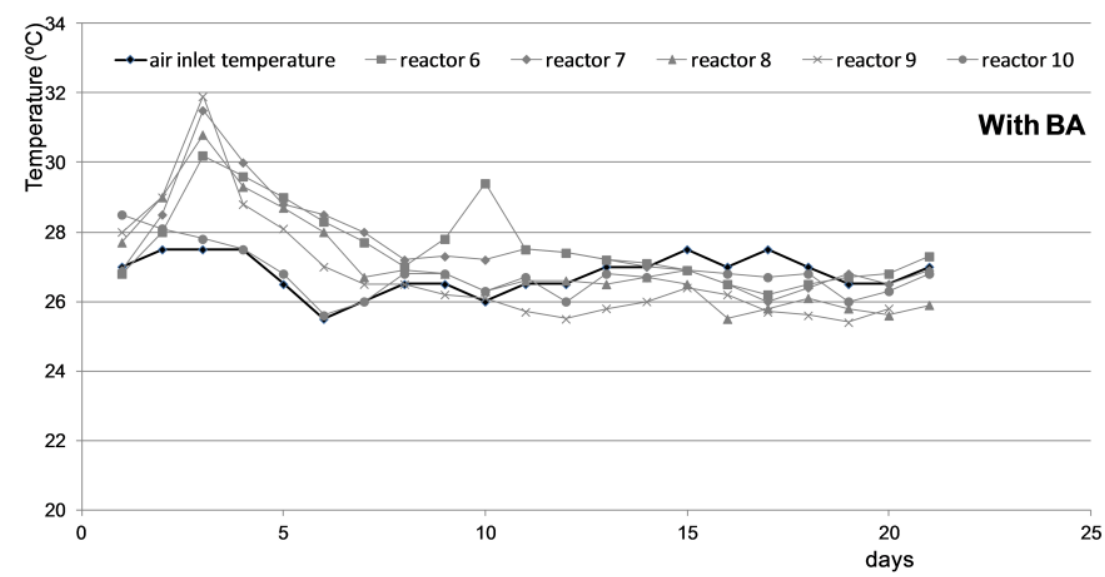

Fig. 4 Evolution of temperature of the input and output air in the reactors.

\section{$2.5 \mathrm{M}$ oisture and volume reduction}

Many works have been published about biodrying waste with an external source of airflow (Sugni et al., 2005; Navaee-Ardeh et al., 2006, 2010; Zhang et al., 2008, 2009; Velis et al., 2009) and with different initial moisture contents, for instance MSW (65.5\%--75\%) (Adani et al., 2002; Zhang et al., 2008, 2009; Rada et al., 2009a; He et al., 2010; Ragazzi et al., 2011; Tambone et al., 2011) or more (80\%) (Zawadzka et al., 2010), pulp and paper mixed sludges (75\%) (Navaee-Ardeh et al., 2006), or sewage sludge (78.4\%--82.6\%) (Zhao et al., 2011; Xu et al., 2011).

Until recently, most research done on biodrying focused on MSW and some studies have used mixed sludge or sewage sludge, but there were no studies about biodrying applied to green wastes or agroindustrial wastes; only research with grape marc (Rada et al., 2009b), which has low biological activity. Biodrying of this kind of organic wastes could be an optional treatment technology, better that composting, because the process time is shorter and the biodried waste could be used as an energy source. In the case of big cities such as Mexico 
City where nowadays wastes must be transported long distances, biodrying could be useful in order to achieve a high reduction of volume and mass of solid waste, rendering it more suitable for short-term storage and transport, both by partially biostabilizing the waste and by reducing its moisture content below the necessary threshold for biodegradation to occur. On the other hand, the biodried green waste could be used in industrial boilers and not only in incineration plants, as is proposed for biodried MSW.

In reactors with lawn grass (Set 1), moisture fell 19.99\% (Reactor 1), 31.75\% (Reactor 2), 35.01\% (Reactor 3), 38.43\% (Reactor 4), and 43.78\% (Reactor 5). Nevertheless, in reactors with lawn grass $+\mathrm{BA}$ (Set 2), the decrease of moisture was higher: $50.17 \%$ (Reactor 6), 65.39\% (Reactor 7), 67.33\% (Reactor 8), 68.14\% (Reactor 9), and 68.94\% (Reactor 10). Final moisture, volume of leachate, evaporated water and weight loss data are shown in Table 2. The volume of biomass was reduced from $20 \%$ to $40 \%$ (data not shown).

In Fig. 5, weight loss due to reduction of moisture is presented. The line which describes weight loss as a function of time changed its slope as the days passed. Thus, weight reduction was greater during the first days. Thereon, the balance that exists between the variables that affect the biodrying is especially important, since it was found that a gradual increase in airflow does not show a proportional reduction (no linear response) in weight or moisture. When the airflow is increased, the waste mass is cooled (the heat is taken away), and therefore, biodrying is affected because in this bioprocess a temperature rise is needed in order to improve the water evaporation. In fact, with a high airflow $(10 \mathrm{~L} / \mathrm{min})$, the biomass was dried mainly by physical effects but not by metabolic heat from aerobic degradation, because the thermophilic phase was not reached. 

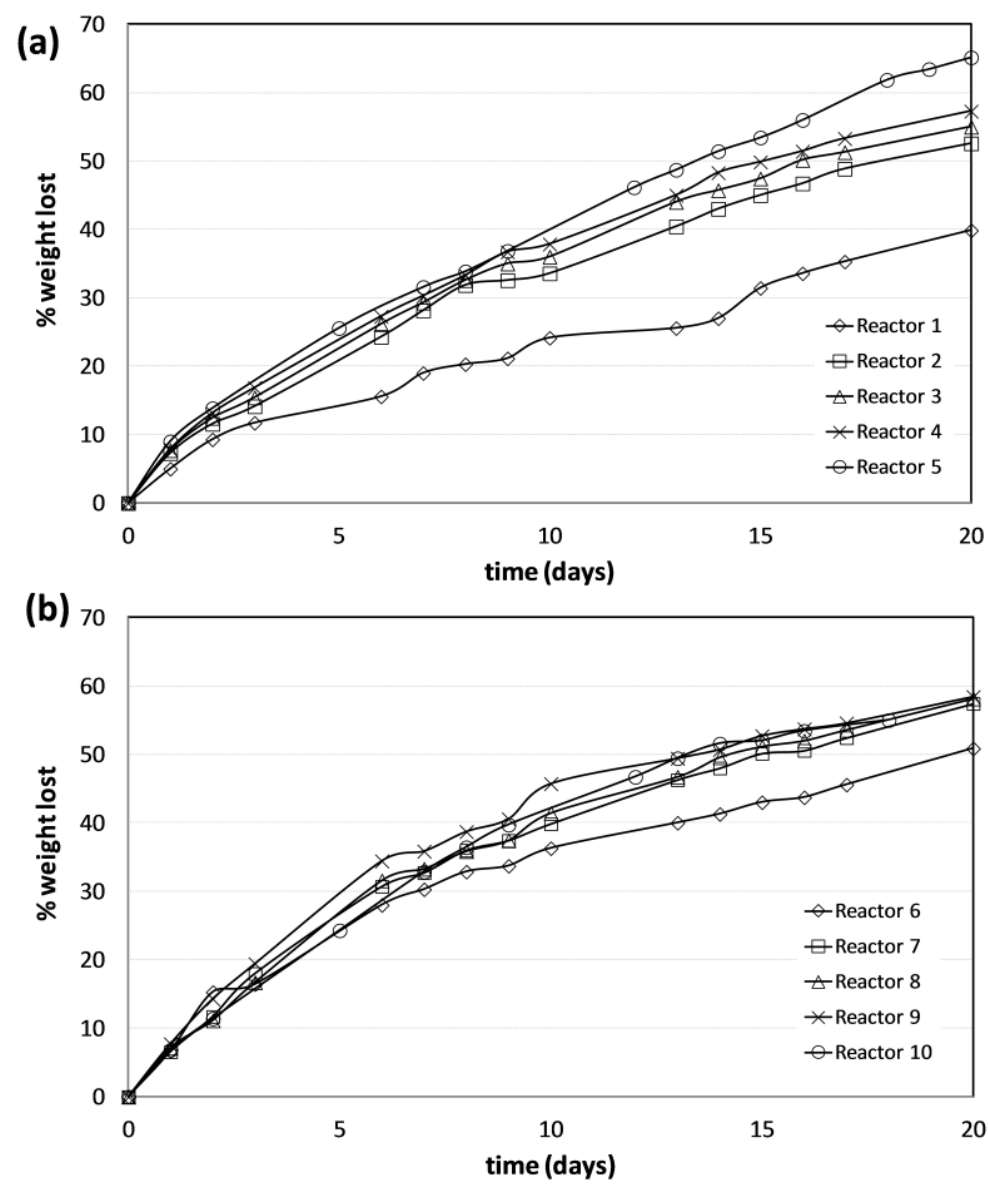

Fig. 5 Evolution of weight loss in reactors. (a) Set 1 (reactors 1--5, fed with grass), and (b) Set 2 (reactors 6--10, fed with grass + BA).

According to Table 2, the final moisture was $15.75 \%$ greater in Reactor 1 than Reactor 2; 4.79\% in Reactor 2 than Reactor 3; 5.24\% in Reactor 3 than Reactor 4, and 8.69\% in Reactor 4 than Reactor 5. Something similar occurred for reactors with grass + BA, where the final moisture was 30.54\% greater in Reactor 6 than Reactor 7 . Nevertheless, it was $5.61 \%$ greater in Reactor 7 than Reactor 8, 2.45\% greater in Reactor 8 than Reactor 9, and $2.52 \%$ greater in Reactor 9 than Reactor 10 . The impact of a higher airflow when waste has BA (Fig. 6b) was negative, because a high airflow takes away the heat affecting the thermophilic phase.

In this research, pruning wastes and wood shavings were used as BA. The effect of BA on biodrying has also been demonstrated by some authors, e.g., Frei et al. (2004) used purchased bark (water content between $40 \%--50 \%$ ) to biodry sewage sludge, and Choi et al. (2001) and Zhao et al. (2011) used sawdust and/or straw (water content between 9\%--11\%). 
In any case, bulking agent is used to promote the airflow through the wastes and facilitate the aerobic fermentation both in biodrying and composting.

In this work, part of the water in the waste was evaporated, levels of moisture in waste below $25 \%$ being reached in reactors $7,8,9$, and 10 (because of the presence of BA). In their works, Velis et al. (2009) reported that commercial process cycles are completed within 7--15 days, with losses of water mostly around 25\%--30\% WW, leading to moisture contents of $<20 \%$ W W. Adani et al. (2002) and Tambone et al. (2011) achieved a diminishment of water content of MSW by $66.7 \%$ and $65.5 \%$ in 9 and 14 days, respectively. Shao et al. (2010) were able to reduce the water content from $73.0 \%$ to $48.3 \%$. Sugni et al. (2005) could not diminish water content more than $53.5 \%$ in 10 days by inverting airflow in order to homogenize the substrate. In the first part of the biodrying in this study, the moisture reduction (from $75 \%$ to $35 \%$ ) was probably provoked mainly by aerobic fermentation, since with this level of moisture the growing of microorganisms is feasible. Below $35 \%$ water content, microbial activity slows down (Gomez et al., 2006) and air convection continues drying the waste to $25 \%$ or less.

However, the airflow increases were not proportional to the decrease of moisture (Fig. 6a) which implies that metabolic heat has more influence in biodrying than loss of water by convection. This influence of fermentation was even more evident in the reactors with BA, since with airflow rates above $2.5 \mathrm{~L} /(\mathrm{min} \cdot \mathrm{kg} \mathrm{dw})$ the final moisture was quite similar after 20 days. On the other hand, an important influence of BA was observed, above all at low airflow. In fact, according to Fig. $\mathbf{6 a}$ and the equation of the best-fit polynomial line, if the airflow was $1 \mathrm{~L} /(\min \cdot \mathrm{kg} \mathrm{dw})$, then the average weight loss in reactors with BA was $25.7 \%$ higher than reactors with only grass. Nevertheless, as the flow rate increased, the smaller this difference was. Therefore, if the airflow was $3 \mathrm{~L} /(\min \cdot \mathrm{kg} \mathrm{dw})$, then the weight loss in reactors with BA was $11.8 \%$ (only $4.4 \%$ if the airflow was $4 \mathrm{~L} /(\min \cdot \mathrm{kg} \mathrm{dw})$ ). 

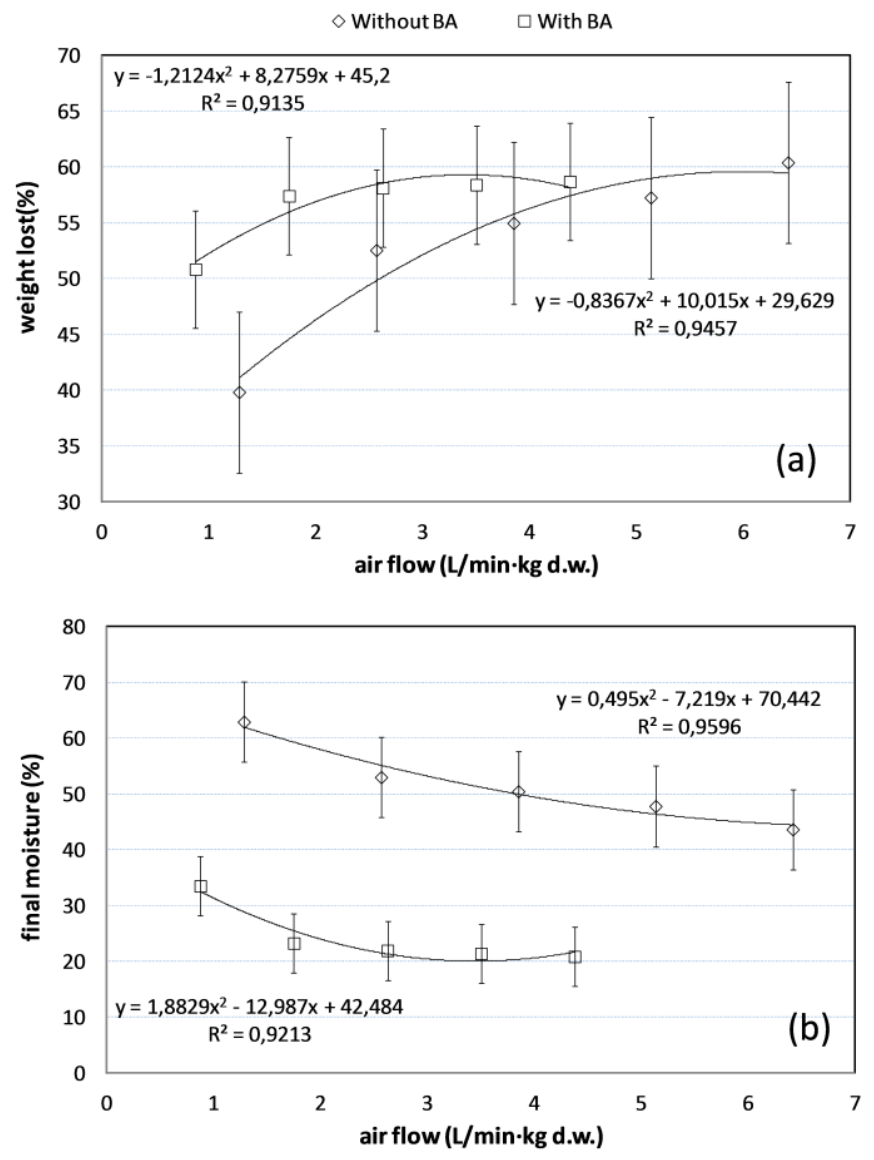

Fig. 6 Influence of airflow on (a) weight loss, and (b) final moisture.

On the other hand, in Table 2 the energy consumption for different airflows is presented and Fig. 7 relates the increase of LHV obtained from the biodrying of wastes with the energy consumption required to generate the airflow. In this figure it is observed that only wastes with BA and low airflow were economically and energetically profitable. Therefore, at the laboratory scale, the biodrying process in the reactors would be cost-effective only with low airflows. 


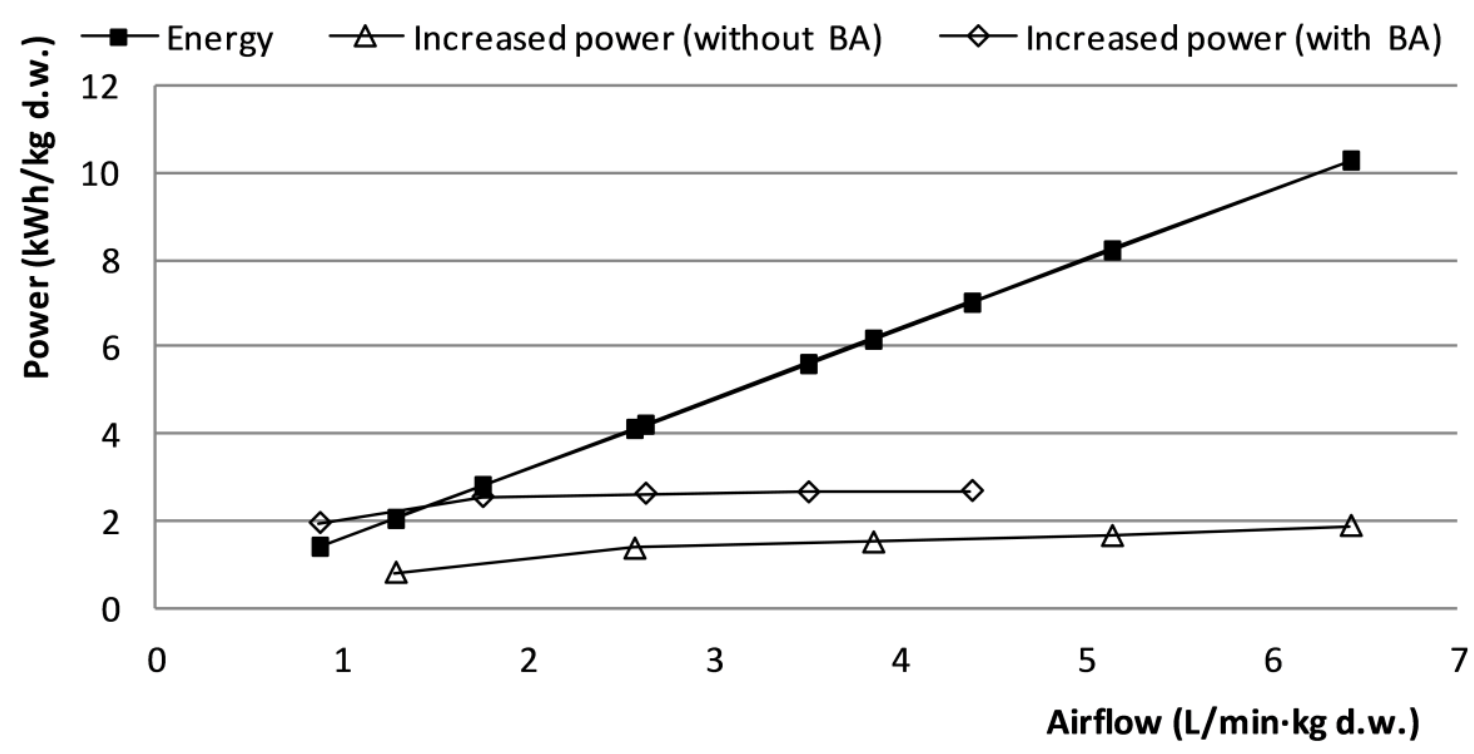

Fig .7 Relationship between the increase of LHV obtained from the biodrying of wastes with the energy consumption required to generate the airflow.

\subsection{Carbon and nitrogen concentration (\%)}

The carbon and nitrogen content is shown in Table 3. Carbon content (\%) did not diminish in this study, suggesting a good biodrying process, because low carbon consumption is necessary in order to maintain the LHV. The nitrogen concentration diminished in all reactors, but this reduction was irregular and did not follow any tendency. The reactors with the highest airflow $(10 \mathrm{~L} / \mathrm{min})$ had the lowest nitrogen concentration at the end of the process.

Table 3 Concentration of carbon and nitrogen initial (i) and final (f)

\begin{tabular}{cccc}
\hline & Reactor & $\mathrm{C}_{\mathrm{f}}(\%)$ & $\mathrm{N}_{\mathrm{f}}(\%)$ \\
\hline & & $\mathrm{C}_{\mathrm{i}}=26.45 \%$ & $\mathrm{~N}_{\mathrm{i}}=3.99 \%$ \\
\cline { 2 - 4 } Set 1 & 1 & 28.32 & 3.90 \\
(without BA) & 2 & 26.01 & 3.45 \\
\hline
\end{tabular}




\begin{tabular}{cccc}
\hline & 3 & 27.53 & 3.63 \\
& 4 & 26.09 & 3.70 \\
& 5 & 26.36 & 2.07 \\
\hline & & $\mathrm{C}_{\mathrm{i}}=25.02 \%$ & $\mathrm{~N}_{\mathrm{i}}=2.84 \%$ \\
\hline Set 2 & 6 & 28.17 & 2.26 \\
(with & 7 & 28.63 & 2.45 \\
BA) & 8 & 28.06 & 2.57 \\
& 9 & 26.44 & 1.82 \\
& 10 & 28.43 & 2.00 \\
\hline
\end{tabular}

\section{Conclusions}

In this work, gardening wastes (grass and pruning wastes) were biodried in reactors for 20 days. A weight loss between $40 \%$ and $57 \%$ and a volume reduction between $40 \%$ and $60 \%$ was reached. Furthermore, adding even a small amount of BA $(15 \%)$ resulted in a greater weight loss; above all in reactors injected with a low airflow, i.e. the reactor with $4 \mathrm{~L} / \mathrm{min}$ air flow had the best results. The BA had a positive influence on biodrying of gardening wastes, improving the air distribution in the waste matrix. Therefore the BA reduced the airflow required as well as the energy needed for the aeration. For higher airflow, weight loss was greater, however, this relationship was not linear. Nevertheless, at a laboratory scale, the biodrying process in reactors would be cost effective only with low airflows.

Additionally, it could be concluded that high airflow affects the biodrying process, because the thermofilic phase is avoided, so that the waste is dried only by physical phenomena and not by biodrying.

\section{Acknowledgments}

The authors are grateful to the Spanish Ministry of Economy and Competitiveness for funding for this study (Project ACI2009-0993) in the program "Convocatoria de Ayudas del Programa Nacional de Internacionalización de la I+D. Subprograma de Fomento de la Cooperación Científica Internacional (ACI-PROMOCIONA)" ("Call for Aid National Programme Internationalization of R \& D. Sub-Building International Scientific Cooperation”).

\section{References}


Adani F, Baido D, Calcaterra E, Genevini P, 2002. The influence of biomass temperature on biostabilization-biodrying of municipal solid waste. Bioresource Technology, 83(3): 173-179 .

Alburquerque J A, Gonzálvez J, García D, Cegarra J, 2006. Effects of bulking agent on the composting of "alperujo": The solid by-product of the two-phase centrifugation method for olive oil extraction. Process Biochemistry, 41(1): 127--132.

Collick A S, Inglish S, Wright P, Steenhuis T S, Bowman D D, 2007. Inactivation of Ascaris suum in a biodrying compost system. Journal of Environmental Quality, 36(5): 1528-1533.

Choi H L, Richard T L, Ahn H K, 2001. Composting high moisture materials: Biodrying poultry manure in a sequentially fed reactor. Compost Science and Utilization, 9(4): 303-311.

Frei K M, Cameron D, Stuart P R, 2004. Novel drying process using forced aeration through a porous biomass matrix. Drying Technology, 22(5): 1191--1215.

Gomez R B, Lima V F, Ferrer S A, 2006. The use of respiration indices in the composting process: a review. Waste Management and Research, 24(1): 37--47.

He P, Tang J, Zhang D, Zeng Y, Shao L, 2010. Release of volatile organic compounds during bio-drying of municipal solid waste. Journal of Environmental Sciences, 22(5): 725--759.

Liang C, Das K C, McClendon R W, 2003. The influence of temperature and moisture contents regimes on the aerobic microbial activity of a biosolids composting blend. Bioresource Technology, 86(2): 131--137.

Navaee-Ardeh S, Bertrand F, Stuar P R, 2006. Emerging biodrying technology for the drying of pulp and paper mixed sludges. Drying Technology, 24(7): 863--878.

Navaee-Ardeh S, Bertrand F, Stuar P R, 2010. Key variables analysis of a novel continuous biodrying process for drying mixed sludge. Bioresource Technology, 101(10): 3379-3387.

Rada E C, Istrate I A, Ragazzi M, 2009a. Trends in the management of Residual Municipal Solid Waste. Environmental Technology, 30(7): 651--661.

Rada E C, Ragazzi M, Fiori L, Antolini D, 2009b. Bio-drying of grape marc and other biomass: a comparison. Water Science and Technology, 60(4): 1065--1070.

Ragazzi M, Rada E C, Antolini D, 2011. Material and energy recovery in integrated waste management systems: an innovative approach for the characterization of the gaseous emissions from residual MSW bio-drying. Waste Management, 31(9-10): 2085--2091. 
Sadaka S, Van Devender K, Costello T, Sharara M, 2010. Composting for biodrying organic materials. FSA1055. University of Arkansas Division of Agriculture. http://www.uaex.edu/Other_Areas/publications/PDF/Consulted07/11/2011.

Shao L M, Ma Z H, Zhang H, Zhang D Q, He P H, 2010. Bio-drying and size sorting of municipal solid waste with high water content for improving energy recovery. Waste Management, 30(7): 1165--1170.

Stasta P, Boran J, Bebar L, Stehlik P, Oral J, 2006. Thermal processing of sewage sludge. Applied Thermal Engineering, 26(13): 1420--1426.

Sugni M, Calcaterra E, Adani F, 2005. Biostabilization-biodrying of municipal solid waste by inverting air-flow. Bioresource Technology, 96(12): 1331--1337.

Tambone F, Scaglia B, Scotti S, Adani F, 2011. Effects of biodrying process on municipal solid waste properties. Bioresource Technology, 102(16): 7443--7450.

Tremier A, de Guardia A, Massiani C, Paul E, Martel J L, 2005. A respirometric method for characterising the organic composition and biodegradation kinetics and the temperature influence on the biodegradation kinetics, for a mixture of sludge and bulking agent to be co-composted. Bioresource Technology, 96(2): 169--180.

Velis C A, Longhurst P J, Drew G H, Smith R, Pollard S J T, 2010. Production and quality assurance of solid recovered fuels using mechanical-biological treatment (MBT) of waste: a comprehensive assessment. Critical Reviews in Environmental Science and Technology, 40(12): 979--1105.

Velis C A, Longhurst P J, Drew G H, Smith R, Pollard S T J, 2009. Biodrying for mechanical-biological treatment of wastes: A review of process science and engineering. Bioresource Technology, 100(11): 2747--2761.

Velis C, Wagland S, Longhurst P, Robson B, Sinfield K, Wise S et al., 2012. Solid recovered fuel: influence of waste stream composition and processing on chlorine content and fuel quality. Environmental Science and Technology, 46(3): 1923--1931.

Wagland S T, Tyrrel S F, Godley A R, Smith R, 2009. Test methods to aid in the evaluation of the diversion of biodegradable municipal waste (BMW) from landfill. Waste Management, 29(3): 1218--1226.

Xu H C, He P J, Wang G Z, Shao L M, Lee D, 2011. Anaerobic storage as a pretreatment for enhanced biodegradability of dewatered sewage sludge. Bioresource Technology, 102(2): $667--671$. 
Yañez R, Alonso J L, Díaz M J, 2009. Influence of bulking agent on sewage sludge composting process. Bioresource Technology, 100(23): 5827--5833.

Zawadzka A, Krzystek L, Ledakowicz S, 2010. Autothermal biodrying of municipal solid waste with high moisture content. Chemical Papers, 64(2): 265--268.

Zhang D Q, He P J, Shao L M, Jin T F, Han J Y, 2008. Biodrying of municipal solid waste with high water content by combined hydrolytic-aerobic technology. Journal of Environmental Sciences, 20(12): 1534--1540.

Zhang D Q, He P J, Yu L Z, Shao L M, 2009. Effect of inoculation time on the bio-drying performance of combined hydrolytic-aerobic process. Bioresource Technology, 100(3): 1087--1093.

Zhao L, Gu W M, He P J, Shao L M, 2011. Biodegradation potential of bulking agents used in sludge bio-drying and their contribution to bio-generated heat. Water Research, 45(6): 2322--2330. 


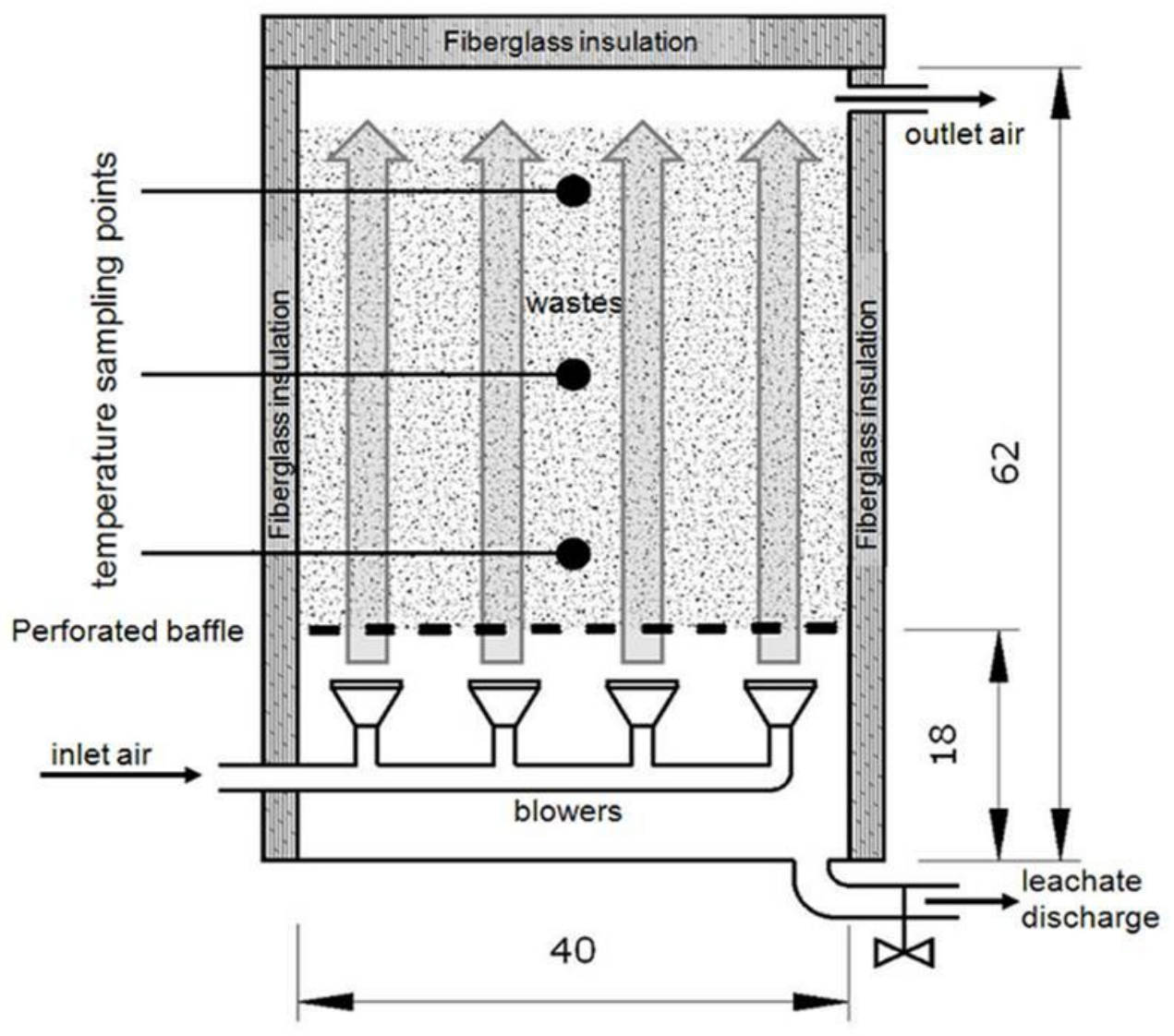

Fig. 1 Scheme of the reactors (dimensions are in $\mathrm{cm}$ ).

Fig. $2 \mathrm{O}_{2}$ and $\mathrm{CO}_{2}$ proportion in the exhaust gas from reactors. (a) Set 1 (reactors fed with grass), and (b) Set 2 (reactors fed with grass + BA).

Fig. 3 Evolution of temperature inside the waste mass in reactors. (a) Set 1 (reactors 1 - 5, fed with grass), and (b) Set 2 (reactors $6-10$, fed with grass + BA).

Fig. 4 Evolution of temperature of the input and output air in the reactors. 
Fig. 5 Evolution of weight loss in reactors. (a) Set 1 (reactors 1 - 5, fed with grass), and (b) Set 2 (reactors $6-10$,fed with grass + BA).

Fig. 6 Influence of airflow on (a) weight loss, and (b) final moisture

Fig .7 Relationship between the increase of LHV obtained from the biodrying of wastes with the energy consumption required to generate the airflow. 